\title{
POTENTIAL BENEFITS OF ELECTRICALY DRIVEN FERRY, CASE STUDY
}

\author{
Tina Perić, Ladislav Stazić, Karlo Bratić \\ University of Split (Croatia)
}

\begin{abstract}
There have been several news articles in the newspapers lately about the introduction of electrically powered ferry boats in Croatia, especially on several shorter routes. This introduction will require serious investigation into potential benefits and also into potential drawbacks to determine if a solution is viable or not. One of those shorter ferry routes in Croatia is a route from peninsula Pelješac to the island of Korčula. The route at the moment is operated by one ferry, driven by four independent propellers, each driven by one diesel engine. This paper is addressing one small aspect of problems, assessing potential benefits of the conversion of a ferry (or replacement with electrically driven ferry) on the mentioned route to electrical power and the impact on the local area due to the reduction of all exhaust gas emissions.
\end{abstract}

Keywords: ferry boat; environment protection; air pollution; electrical propulsion

\section{Introduction}

According to the "Clean energy for EU islands initiative"1), the introduction of the sustainable, low-cost energy will bring "improved air quality, lower greenhouse gas emissions, and less impact on islands' natural environments". One of the aspects of that approach is introduction of the electrically driven ferries which will remove the impact of the exhaust gas emissions from classic ferries which are in use today. This idea is already researched numerous times (Gagatsi et al. 2016; Anwar et al. 2020), investigating various aspects and consequences of the use. Some studies are researched in Croatia, e.g. the study of (Pfeifer et al. 2020), analyzing the potential of the application of clean energy on islands in central Dalmatia.

The Croatian coast with islands is one of the most indented in the world. There are more than 1,200 islands and islets, of which 50 are inhabited. In parallel with the mentioned initiative, there is an idea to connect inhabited islands with clean energy ferries, propelled by an electrical source ${ }^{3)}$. This idea is present in various parts of the world, there are many attempts to investigate the application of electrical power for the ferry propulsion (Mashayekh et al. 2012; Zulfaidah et al. 2020; Nguyen et al. 2020). 
The application of electrical ferries on routes in Croatia is still under different types of the research (Pfeifer et al. 2020; Ančić et al. 2020).

This paper is addressing only one small aspect of problems, assessing potential benefits of the introduction of the electrically driven ferry on one of the shortest ferry routes in Croatia due to the reduction of all exhaust gas emissions. All other aspects (like economical, etc.), are not addressed in the paper, remaining as a good theme for more comprehensive study.

\section{Analyzed route \& traffic}

The analyzed route between Orebić and Dominče (Island of Korčula) is one of the shortest ferry routes in Croatia, its total length is slightly over $2 \mathrm{Nm}$ (Figure 1).

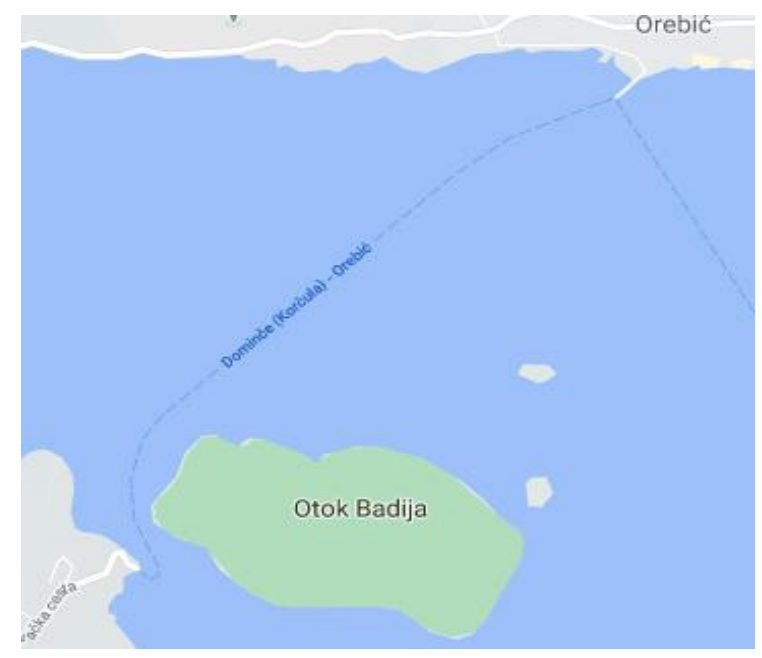

Figure 1. Analyzed ferry route ${ }^{3)}$

The ferry operating on the route (Table 1 and Figure 2) has classic diesel engine propulsion.

Table 1. Vessel data ${ }^{4}$

\begin{tabular}{|l|c|}
\hline Loa & $87.6 \mathrm{~m}$ \\
\hline Lbp & $80.0 \mathrm{~m}$ \\
\hline $\mathrm{B}$ (moulded) & $17.5 \mathrm{~m}$ \\
\hline $\mathrm{D}$ (moulded to main deck) $3.7 \mathrm{~m}$ & $3.7 \mathrm{~m}$ \\
\hline Draught max. & $2.4 \mathrm{~m}$ \\
\hline Deadweight at $2.4 \mathrm{~m}$ & $800 \mathrm{~m} . \mathrm{t}$ \\
\hline Gross tonnage & 2,438 \\
\hline Speed in trial at draft of 2,2 $\mathrm{m}$ & $11.5 \mathrm{knots}$ \\
\hline
\end{tabular}




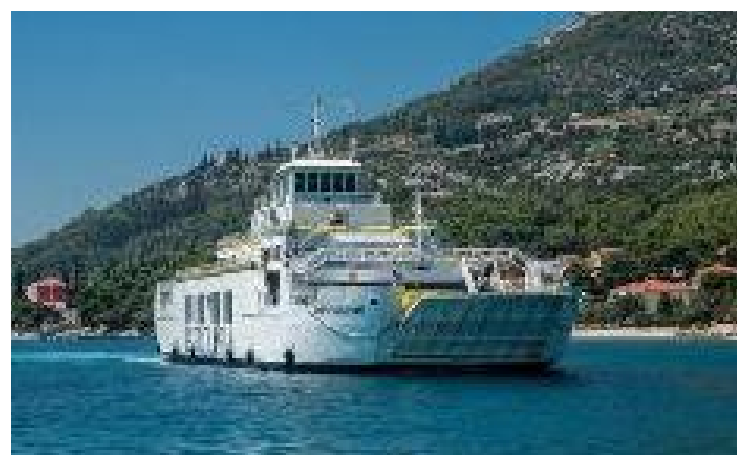

Figure 2. Ferry operating the route ${ }^{5)}$

Details about the main machinery components are presented in the Table 2.

Table 2. Vessel main machinery ${ }^{4)}$

\begin{tabular}{|l|l|}
\hline Main engines & $4 \times 400 \mathrm{~kW}$ \\
\hline Propulsion unit & $4 \times 400 \mathrm{~kW}$ \\
\hline Electric power plant & $2 \times 240 \mathrm{kVA}+1 \times 90 \mathrm{kVA}$ \\
\hline
\end{tabular}

The ferry crosses several times daily, departure schedule varies according to the season and temporary requirements (Figures 3 and 4).

\begin{tabular}{|c|c|c|}
\hline DOMINČE & Daily & OREBIĆ \\
\hline & & 4 \\
\hline $00: 10^{*}$ & I & $00: 30^{*}$ \\
\hline $05: 30^{*}$ & II & $06: 15^{*}$ \\
\hline $07: 00$ & III & $07: 20$ \\
\hline $08: 10$ & IV & $08: 30^{*}$ \\
\hline $09: 40$ & V & $10: 00$ \\
\hline $11: 10$ & VI & $11: 30$ \\
\hline $12: 40$ & VII & $13: 00$ \\
\hline $14: 10$ & VIII & $14: 30$ \\
\hline $15: 10^{*}$ & IX & $15: 45^{*}$ \\
\hline $16: 10$ & X & $16: 30$ \\
\hline $17: 40$ & XI & $18: 00$ \\
\hline $19: 10$ & XII & $19: 30$ \\
\hline $20: 00$ & XIII & $21: 10$ \\
\hline $22: 10$ & XIV & $22: 30$ \\
\hline
\end{tabular}

Figure 3. Off-season sailing schedule ${ }^{6}$ 


\begin{tabular}{c|c|c|} 
DOMINČE & Daily & OREBIĆ \\
\hline & & \\
\hline $00: 10$ & I & $00: 30$ \\
\hline $03: 40^{*}$ & II & $04: 00^{*}$ \\
\hline $05: 10$ & III & $05: 30$ \\
\hline $06: 10$ & IV & $06: 30$ \\
\hline $07: 00$ & V & $07: 20$ \\
\hline $08: 00$ & VI & $08: 30$ \\
\hline $09: 00$ & VII & $09: 00$ \\
\hline $10: 00$ & VIII & $10: 30$ \\
\hline $11: 00$ & IX & $11: 30$ \\
\hline $12: 10$ & X & $12: 35$ \\
\hline $13: 00$ & XI & $13: 30$ \\
\hline $14: 00$ & XII & $14: 30$ \\
\hline $15: 00$ & XIII & $15: 30$ \\
\hline $16: 00$ & XIV & $17: 00$ \\
\hline $17: 30$ & XV & $18: 00$ \\
\hline $19: 00$ & XVI & $19: 30$ \\
\hline $20: 00$ & XVII & $21: 15$ \\
\hline $22: 10$ & XVIII & $22: 30$ \\
\hline
\end{tabular}

Figure 4. Season sailing schedule ${ }^{6}$

\section{The estimation}

The methodology used in the estimation of the exhaust gas emissions from the ferry is the method described by (Trozzi 2010) and recommended by "EMEP EEA air pollutant emission inventory guidebook 2016, Introduction" 7) and "EMEP/EEA air pollutant emission inventory guidebook 2019 " 8 .

According to the methodology, there are two approaches, based on fuel consumptions or engine power. As the vessel fuel consumption is not known, the estimation will be based "on engines power and time spent in the different navigation phases" (Trozzi 2010)

According to the owner of the vessel ${ }^{5)}$, the transit time from one to the other port is 15 minutes, and there are 14 double crossings during off-season period (Figure 3 ) and 18 during full season period (Figure 4).

The calculation of the air pollutants is performed as per the Equation" (Trozzi 2010):

$$
E=T * P * L F * E F
$$

where

$$
\begin{aligned}
& \mathrm{E} \text { - emission }[\mathrm{kg}] \\
& \mathrm{T} \text { - time }[\mathrm{h}]
\end{aligned}
$$


$\mathrm{P}$ - engine nominal power $[\mathrm{kW}]$

LF - engine load factor [\%]

$\mathrm{EF}$ - emission factor $[\mathrm{kg} / \mathrm{kW}]$

Time is calculated as multiplication of the crossing time and number of crossings:

$T=n * t$

where

$\mathrm{n}$ - number of crossings

$\mathrm{t}$ - crossing time $[\mathrm{h}]$

During off season time is calculated to $7[h]$, while in the season time it is $9[h]$. Engine nominal power "P" is shown in Table 2 and equals:

$4 \times 400=1600[\mathrm{~kW}]$

Engine load factor is calculated with corrections due to uncertainties (navigation in shallow water, changes in wind and sea conditions) and the specific circumstances (maneuvering and short passage combined). Considering all corrections given by (Insel 2008), engine load factor LF is calculated to 24.65 [\%].

Emission factors depend of the type of engine, fuel used for the engine and the year of construction. This ship has been built in 2004, that year is accepted as year of the construction of engines. According to the year, ship belongs to the Tier I group. The ship is permanently using LS MDO, the only fuel available on the market. Emission factors for the analyzed vessel are taken from the study performed in Netherlands (Van der Gon \& Hulskotte 2010) and are presented in Table 3.

Table 3. Vessel emission factors (Trozzi 2010)

\begin{tabular}{|l|l|}
\hline NOx & $10.6 \mathrm{~g} / \mathrm{kWh}$ \\
\hline VOC & $1.5 \mathrm{~g} / \mathrm{kWh}$ \\
\hline PM & $0.9 \mathrm{~g} / \mathrm{kWh}$ \\
\hline CO & $1.8 \mathrm{~g} / \mathrm{kWh}$ \\
\hline CO2 & $685.1 \mathrm{~g} / \mathrm{kWh}$ \\
\hline
\end{tabular}

By inserting the presented values in Equation 1, daily quantity of air pollutants can be estimated (Table 4).

Table 4. Estimated annual air emissions

\begin{tabular}{|l|l|}
\hline NOx & $12.72 \mathrm{t}$ \\
\hline VOC & $1.80 \mathrm{t}$ \\
\hline PM & $1.08 \mathrm{t}$ \\
\hline $\mathrm{CO}$ & $2.16 \mathrm{t}$ \\
\hline $\mathrm{CO} 2$ & $822.11 \mathrm{t}$ \\
\hline
\end{tabular}




\section{Conclusions}

Introduction of the electrically driven ferry on the route between peninsula of Pelješac and island of Korčula will affect the environment in the area, reducing the overall air emissions significantly. According to the performed calculation, the proposed introduction will reduce the air pollutant emissions in the channel by 12.72 tons of NOx, 1.80 tons of Volatile Organic Compounds, 1.08 tons of Particulate Matters and 2.16 tons of Carbon monoxide. On top of those pollutants, engines will discharge 822.11 tons of $\mathrm{CO}_{2}$. Additional benefits are possible with the replacement of the passenger boat (on the same route) with electrically powered one. The presented estimate shows that potential benefits are significant, but there is the need for larger multidisciplinary analysis which will consider many more aspects than this small study.

Acknowledgments. Part of the research for this article was performed using the equipment obtained through the Project named "Functional integration of the University of Split, PMFST, PFST and KTF-ST through development of scientific and research infrastructure in three faculties building", contract number KK.01.1.1.02.0018.

\section{NOTES}

1. European Comission: Clean energy for EU islands initiative. Available from: https:/ec.europa.eu/energy/topics/markets-and-consumers/clean-energy-euislands_en?redir $=1$ [accessed $3^{\text {rd }}$ April 2021]

2. Morski. hr. The Nordic countries have introduced electric ferries, this is when Jadrolinija plans“ (in Croatian). Available from: https://morski.hr/2021/02/21/ nordijske-zemlje-su-uvele-elektricne-trajekte-evo-kad-planira-jadrolinija/, [accessed 6 $6^{\text {th }}$ April 2021]; Slobodna Dalmacija; „GREEN ENERGY Electric ferries will also connect our islands: 'We are able to build a ship with a capacity of 60 cars and 350 passengers. It would sail 12 miles without interruption" (in Croatian), available at: https://more.slobodnadalmacija.hr/om/nautika/trajektina-struju-povazat-ce-i-nase-otoke-u-stanju-smo-izgraditi-brod-kapaciteta-60automobila-i-350-putnika-bez-prekida-bi-plovio-12-milja-1069123, [accessed $6^{\text {th }}$ April 2021]

3. Google maps. Available from: https://www.google.com/maps/@42.959833,17.1 $729408,14.25 \mathrm{z}$, [accessed $6^{\text {th }}$ April 2021]

4. Hrvatska brodogradnja-Jadranbrod. Available from: http://hb.hr/wp-content/ uploads/2014/12/ferries.pdf. [accessed $7^{\text {th }}$ April 2021]

5. Jadrolinija. Sveti Krševan. Available from: https://www.jadrolinija. hr/o-nama/brodovi/trajekti/trajekti-lokalnih-linija/sveti-krsevan. [accessed $7^{\text {th }}$ April 2021] 
6. Korcula info.com. Ferry Orebic - Korcula (Domince) Car Ferry. Available from: https://www.korculainfo.com/ferries/ferry-orebic-korcula/. [accessed $8^{\text {th }}$ April 2021]

7. European Environment Agency, EMEP/EEA air pollutant emission inventory guidebook 2016; Technical guidance to prepare national emission inventories, (Denmark, 2016). ISBN 978-92-9213-806-6. doi:10.2800/247535. Available from: https://www.eea.europa.eu/publications/emep-eea-guidebook-2016, [accessed 8th April 2021].

8. European Environment Agency, EMEP/EEA air pollutant emission inventory guidebook 2019 - Update Oct. 2020. Available from: https://www.eea.europa. eu/publications/emep-eea-guidebook-2019. [accessed 8th April 2021

\section{REFERENCES}

Ančić, I. et al., 2020. Alternative power options to reduce carbon footprint of ro-ro passenger fleet: A case study of Croatia. Journal of Cleaner Production 122638. doi: 10.1016/j.jclepro.2020.122638

Anwar, S. et al., 2020. Towards Ferry Electrification in the Maritime Sector. Energies 19961073, 13(24). doi: 10.3390/en13246506

Gagatsi, E., et al., 2016. Exploring the Potentials of Electrical Waterborne Transport in Europe: The E-ferry Concept. Transportation Research Procedia 14, 1571 - 1580. doi: 10.1016/j.trpro.2016.05.122

Insel, M., 2008. Uncertainty in the analysis of speed and powering trials. Ocean Engineering 35(11-12), 1183-1193. doi: 10.1016/j. oceaneng.2008.04.009

Mashayekh, S., et al., 2012. Optimum sizing of energy storage for an electric ferry ship. In: IEEE Power and Energy Society General Meeting. doi:10.1109/pesgm.2012.6345228

Nguyen, H.P. et al., 2020. The electric propulsion system as a green solution for management strategy of $\mathrm{CO} 2$ emission in ocean shipping: A comprehensive review. In: International Transactions on Electrical Energy Systems, pp. 12580. doi: 10.1002/2050-7038.12580

Pfeifer, A. et al., 2020. Challenges and opportunities of zero emission shipping in smart islands: a study of zero emission ferry lines. eTransportation (100048). doi: 10.1016/j.etran.2020.100048

Trozzi, C., 2010. Emission estimate methodology for maritime navigation. Rome: Techne Consulting. Available from: http:/www.epa.gov/ ttnchie1/conference/ei19/session10/trozzi.pdf. [acessed $8^{\text {th }}$ April 2021]

Van der Gon, H.D. \& Hulskotte, J., 2010. Methodologies for estimating shipping emissions in the Netherlands. A documentation of currently used emission factors and related activity data. Bilthoven. 
Zulfaidah, A., \& Santoso, B., 2020. Main engine calculation for ferry Ro-Ro 500 DWT ship using electric propulsion. In: IOP Conference 2020. 845(1), 012011. doi: 10.1088/1757-899X/845/1/012011

Tina Perić

Web of Science Researcher ID: T-1751-2019

Faculty of Maritime Studies

University of Split

Split, Croatia

E-mail: tperic@pfst.hr

$\triangle$ Ladislav Stazić

http://orcid.org/0000-0002-9921-3895

Faculty of Maritime Studies

University of Split

Split, Croatia

E-mail: 1stazic@pfst.hr

$\triangle$ Karlo Bratić

ResearcherID A-9211-2019

Faculty of Maritime Studies

University of Split

Split, Croatia

E-mail:kbratic@pfst.hr 